Якщо вихователь групи продовженого дня любить дітей та свою справу, творчо ставиться до роботи, ним створено затишний кабінет- це сприятиме якісному результату співпраці. А якщо дитина має піднесений настрій, відчуває підтримку й отримує високу оцінку своєї роботи, результативність іiі діяльності автоматично підвищується. Логічно передбачити і задоволення учнів від перебування у групі продовженого дня, оскільки у вихованні все має грунтуватися на особистості педагога. Будь-яка програма викладання чи метод виховання, хоч би якими добрими вони не були, не перейшовши в переконання вихователя, залишаються мертвими, такими, що не мають ніякої сили в дійсності [3, с. 43].

К. Ушинський зауважував, що «найпильніший контроль у цій справі не допоможе. Вихователь ніколи не може бути сліпим виконавцем інструкції. Немає сумніву, що багато чого залежить від загального розпорядку в закладі, але найголовніше завжди залежить від особи вихователя, що стоїть віч-на-віч із вихованцем» [8, с. 137].

Переконані, що вплив особистості педагога на молоду душу становить ту виховну силу, якої не можна замінити на підручники ні моральними сентенціями, ні системою покарань і заохочень, оскільки дух закладу живе не в стінах, не на папері, а в характері більшості вихователів і звідти вже переходить у характер вихованців.

\title{
Література
}

1. Жерносек И. Ф. Повышение квалификации педагогических кадров / И. Ф. Жерносек // Под. ред. И. Ф. Жерносека, М. Ю. Красовицького, С. В. Крисюка. К. : Вища школа, 1992. - 190 с.2. Кочерга О. Розвиток психологічної компетентності вчителя початкової школи / Олександр Кочерга // Рідна школа. - 2013. - № 11. - С. 52 53. 3. Мельничук С. К. Д. Ушинський про педагогічну підготовку вчителя початкових класів / С. Мельничук // Початкова школа. - 2013. - № 1. - С. 43-44. 4. Митник О. Психолого-педагогічні засади підготовки вчителя у системі післядипломної освіти до реалізації компетентнісного підходу/ Олександр Митник// Рідна школа. - 2013. № 11. - С. 42-44. 5. Моделирование педагогических ситуаций / под. ред. Ю. Н. Кулюткина, Г. С. Сухогубской. - М. : Просвещение, 1981. - 148 с. 6. Савченко О. Я. Уміння вчитися як ключова компетентність загальної середньої освіти / О. Я. Савченко // Компетентнісний підхід у сучасній освіті: світовий досвід та українські перспективи / за заг. ред. О. В. Овчарук. - К. : К.І.С., 2004. - С. 34-46. 7. Сухомлинський В. О. Три елементи школи / В. О. Сухомлинський. - К. : Акта, 2012. - 537 с. 8. Ушинський К. Д. Твори / К. Д. Ушинський. - К. : Рідна школа. -1954. - 368 с.

УДК 371.3:330

Юлія Люлькова

\section{ЕКОНОМІЧНІ ЗНАННЯ У ЗМІСТІ ГЕОГРАФІЧНОЇ Й ЕКОНОМІЧНОЇ ШКІЛЬНОЇ ОСВІТИ}

Люлькова Ю. М. Економічні знання у змісті географічної й економічної шкільної освіти.

У статті визначено місце економічних знань у змісті географічної й економічної шкільної освіти. 3'ясовано, що економічні знання варто розуміти як систему уявлень, понять i термінів, фактів, відображення закономірностей, законів i теорій, світоглядних ідей, що формують ставлення особистості до різних явищ соціальноекономічного й суспільного життя.

Ключові слова: економічні знання, шкільний курс географії, шкільний курс економіки, освітня компетенція, економічна компетентність, географічна компетентність. 
Люлькова Ю. Н. Экономические знания в содержании географического и экономического школьного образования.

В статье определено место экономических знаний в содержании географического и экономического образования. Определено, что экономические знания следует понимать как систему представлений, понятий и терминов, фактов, отображение закономерностей, законов и теорий, мировоззренческих идей, которые формируют отношение личности к разным явлениям социально-экономической и общественной жизни.

Ключевые слова: экономические знания, школьный курс географии, школьный курс экономики, образовательная компетенция, экономическая компетентность, географическая компетентность.

Lyulkova Yu. N. Economic knowledge in the content of its geographical and economic school education.

The articledefines the place ofeconomic knowledgein the content ofits geographical and economiceducation.Determined that theeconomic knowledgeto be understoodas a system ofideas, concepts andterms, facts, displaying patterns, laws and theories, philosophical ideasthat form therelationship between the individualtodifferent phenomenaof socio-economic and public life.

Key words: economic knowledge, school geography course, school economics course, subject competence, economic competence, geographic competence.

На сучасному етапі розвитку географічної думки відбувається перегляд i переосмислення змісту, форм, методів і принципів розроблення новітніх підходів до формування економічних компетенцій у межах теорії вітчизняної економічної науки й соціально-економічної географії. Окреслений процес зумовлює необхідність у створенні науково-методичних праць, в основу яких була б покладена галузева диференціація теоретико-методичних досліджень, які послідовно розв'язують питання формування географічних та економічних знань.

Зміст економічної освіти 3 предметів, зокрема географії й економіки, у Державному стандарті середньої освіти належить до різних освітніх галузей («Природознавства» і «Суспільствознавства» відповідно), що, на наше переконання, певною мірою гальмує вироблення цілісного сприйняття довкілля й господарської діяльності людини у процесі її навчання та життєдіяльності.

Проблеми вдосконалення змісту й методики навчання географії та економіки на сучасному етапі досліджували вітчизняні економ-географи й методисти М. Багров, М. Баранський, Н. Бірюкова, Л. Булава, Й. Гілецький, Ф. Заставний, С. Кобернік, В. Корнєєв, М. Криловець, Л. Круглик, П. Масляк, Т. Назаренко, Я. Олійник, М. Паламарчук, М. Пістун, А. Сиротенко, О. Топузов, О. Топчієв, Б. Яценко та інші.

Мета статmi - окреслити структуру економічних знань у змісті економічної й географічної шкільної освіти.

Загальноприйнятий у сучасній педагогіці принцип науковості навчання вказує на те, що зміст освіти має формуватися 3 фонду знань, накопичених і прийнятих сучасною наукою. Категорія «знання» $\epsilon$ родовою щодо різних видів, які виокремлюються в ії межах (буденне, частково наукове, філософське, навчальне).

Науково-довідкове видання з педагогіки [3] визначає знання як особливу форму духовного засвоєння результатів пізнання, процесу відображення дійсності, яка характеризується усвідомленням їх істинності. Знання передаються шляхом цілеспрямованого навчання. Водночас навчання - це «цілеспрямований процес передачі 
і засвоєння знань, умінь, навичок і способів пізнавальної діяльності людини» [3, с. 223].

Науковці В. Краєвський та І. Лернер виокремили складники змісту навчання: 1) знання про природу, суспільство, техніку, людину, способи діяльності; 2) досвід виконання відомих способів діяльності, що втілюються разом із знаннями у навичках і вміннях особистості; 3) досвід творчої діяльності; 4) досвід емоційно-ціннісного ставлення до дійсності [8, с. 146].

Аналізуючи специфічність першого елементу змісту освіти, автори зазначають, що «знання являють собою всю накопичену людством об'єктивну інформацію про світ, у тому числі про способи діяльності»[8, с. 147]. Проте в цьому підході зберігається протиставлення знань іншим елементам культури, зокрема, у більш ранній роботі І. Лернера і М. Скаткіна обгрунтовується позиція, що до змісту освіти мають вноситися всі елементи культури, а не лише система знань [4, с. 47]. Знання $\epsilon$ одним із чотирьох основних структурних елементів змісту освіти як педагогічної моделі людської культури, що представлена в аспекті соціального досвіду. При цьому визначальний елемент становить знання як «досвід пізнавальної діяльності, зафіксований у формі їі результатів» [6, с. 159]. Оскільки кожний попередній елемент у змісті навчання слугує передумовою для переходу нанаступний, оволодіння економічними знаннями за принципом послідовності уможливлює набуття системи економічних знань під час вивчення географії.

У сучасній педагогічній науці зберігається традиційне виокремлення категорії «знання» із змісту навчання відповідно до концепції І. Лернера. У державній національній програмі «Освіта» (Україна XXI століття) як стратегічне завдання реформування змісту освіти в Україні зазначено вироблення державних стандартів і відповідне формування на їх основі системи й обсягу знань, умінь, навичок, творчої діяльності. Вітчизняні автори сучасних підручників і навчальних посібників 3 дидактики (В. Бондар [2], В. Лозова, Г. Троцко) також дотримуються підходу до змісту освіти як системи чотирьох компонентів соціального досвіду: знання, досвід здійснення способів діяльності (вміння і навички), досвід творчої діяльності, емоційно-ціннісне ставлення до світу.

Констатуємо певною мірою протиставлення знань іншим компонентам змісту навчання - способам діяльності, світогляду, складникам культури, і тому доцільно розрізняти широке і конкретне розуміння категорії «знання». У широкому розумінні знання відображаються у всіх елементах змісту освіти і в усіх функціях знань. Зокрема, в українському педагогічному словнику наголошується на двох соціальних функціях, які виконують знання: а) матеріалізуються в певні технічні пристрої, технологічні процеси; б) перетворюються на переконання і стають керівництвом до практичної дії [3, с. 137]. Отже, в конкретному значенні під знаннями варто розуміти один із компонентів змісту освіти, переважно інформаційний аспект змісту навчального матеріалу, який становить систему понять і чітких визначень, фактів, теорій, правил, законів, формул, закономірностей і принципів, що є лише одним із складників змісту процесу навчання.

Традиційно структура знань передбачає певні їх види, що мають бути передбачені в програмах, підручниках і в самому навчальному процесі: основні поняття і терміни, без яких не можна зрозуміти жодного тексту,жодного елементу знань; факти повсякденної дійсності і науки; основнізакони науки, що розкривають зв'язки і відношення між різними об'єктами і явищами дійсності; теорії, які містять систему наукових знань про певну сукупність об'єктів і про методи пояснення i передбачення явищ цієї предметної галузі; наукові і соціальні ідеї, які, ставши 
надбанням особистості, зумовлюють іï ставлення до світу, іiі ідеали і спрямованість діяльності; знання про способи діяльності, методи пізнання й історії отриманих знань, історії науки; оцінні знання, знання про норми ставлення до різних явищ життя, що прийняті в суспільстві [4, с. 48; 5].

Отже, знання розуміються як система уявлень, понять і термінів, фактів, як відображення закономірностей, законів і теорій, світоглядних ідей, що формують ставлення особистості до різних явищ суспільного життя. Проблематика процесу формування знань передбачає також пізнання процесів засвоєння знань, їх закріплення, застосування до розв'язання практичних і теоретичних завдань.

Науковці Г. Костюк, А. Усова визначають економічні знання як сукупність ідей, які адекватно відбивають властивості й закономірності економічних процесів, перевіряються практикою i слугують засобом iї перетворення. Дослідниця Л. Новикова, цілком погоджуючись із вищезазначеними дослідниками, вважає за доцільне трактувати поняття «економічні знання» як перевірений практикою результат пізнання економічної діяльності, адекватне відбиття іiі в мисленні учнів через сукупність уявлень, понять, суджень, теорій, ідей [7, с. 37].

Отже, знання й мислення перебувають у тісному взаємозв'язку, оскільки мислення грунтується на знаннях, водночас у процесі обмірковування мислення продукує нові знання.

Саме економічні знання сприяють розвитку економічного й географічного мислення, оскільки без економічних знань суспільна географія $\epsilon$ нагромадженням статистичних фактів, економічних і соціальних об'єктів, які мають лише просторову організацію.

До змісту економічних знань, на думку науковця О. Шпака, входять:а) основи економічної теорії, засади демократичних поглядів i економічних відносин; б) економічна стратегія держави у сфері виробництва на сучасному етапі; в) історія розвитку економічних поглядів і економічних відносин; г) економіка своєї країни та інших держав; г) економіка району і базового підприємства (завод, фабрика); д) економічні переконання, погляд, світогляд [9, с. 111].

Узагальнимо, що в науковій і довідковій педагогічній літературі (педагогічних словниках) економічна освіта подається як підготовка спеціалістів у різних напрямках роботи в народному господарстві, відповідно географічна й економічна освіта підготовка спеціалістів-географів у ВН3, що зумовлює логічне розмежування загальної й спеціальної (вищої) економічної освіти.

Оскільки структура дійсності відображена у предметній структурі наукового знання, то зміст навчання варто розглянути під кутом зору предметної структури.

Економічні знання, як основи відповідної науки, нині представлені в практиці школи в окремому навчальному предметі- «Економіка». Оскільки економіка $\epsilon$ відносно новим навчальним предметом, як інваріантний складник уведений до навчальних планів з 2001 року (у структурі 12-річної школи вивчення віднесено на 11 клас), традиційно елементи економічних знань, що мають загальноосвітне значення, внесено до змісту інших навчальних предметів - історії, географії, математики. У розробленому переліку географія $\epsilon$ провідною дисципліною щодо формування економічних знань, що зумовлює актуальність дослідження саме економічної спрямованості географічної освіти.

Загальнодидактичну проблему раціонального співвідношення між географічною наукою і шкільним предметом «Географія» та внесення до ії змісту економічних знань досліджували М. Баранський, В. Максаковський, М. Ковалевська, Л. Панчешнікова, Л. Круглик та інші. Сучасна географічна наука збагатилася новими напрямками, 
зокрема в галузі суспільно-географічних досліджень, як-от: геоглобалістика, геоекономіка, геополітика і політична географія (особливо, електоральна географія), маркетингова географія. Водночас в українській школі превалює підхід до винесення нових знань або в окремі предмети (екологія, економіка, громадянська освіта), або в окремі курси за вибором відповідно до профілю і напряму навчання, наприклад, «Глобальна географія», «Комерційна географія», або в надінтегровані утворення на зразок «Довкілля» в основній школі чи «Природознавства», «Людина і природа», «Людина і світ» у старшій школі для окремих напрямів навчання.

Ураховуючи суспільну значущість, економічні знання слід уводити якомога раніше як елемент загальноосвітньої підготовки учнів, саме в структурі шкільних курсів географії, які в часі передують вивченню економіки. Окрім цього, економічні знання під час вивчення географії необхідні учням задля розуміння суті явищ, геопросторову організацію яких і намагається пояснити географія як наука. Про важливість економічних знань для соціально-економічної географії як науки свідчить той факт, що в найбільш визнаному і поширеному в середовищі географів понятійнотермінологічному словнику «Соціально-економічна географія» Е. Алаєва [1] економіка, як і соціологія, названа «материнською» $[1$, с. 26], «вихідною» $[1$, с. 10] наукою щодо соціально-економічної географії; понятійно-термінологічній системі «Економіка» присвячений окремий розділ, що передує понятійно-термінологічній системі «Соціально-економічна географія». Як останній аргумент взаємозв'язку між географією й економікою Е. Алаєв наводить незаперечний факт: «усі економікогеографічні і соціально-географічні процеси і відношення, зокрема закономірності, підлягають дії економічних закономірностей» [1, с. 25].

Підсумовуючи сказане, вважаємо, що у шкільних курсах економічної i соціальної географії України та світу економічні знання мають бути представлені як основи науки «економіка», при цьому провідним компонентом змісту навчання залишається географія. Метою вивчення шкільних курсів економічної і соціальної географії повинна стати побудова міждисциплінарної системи знань 3 суспільної географії та економіки. Під основами науки розуміють «найважливіші факти, поняття, теорії, методи, мову науки та їі практичне застосування, відібрані відповідно до цілей навчання і вікових можливостей учнів» [4, с. 62], що дозволяє виокремити рівні: економічні поняття; економічні явища і відношення між ними; економічні закони, розглядаючи їх у змісті навчальних предметів «географія» та «основи економіки» за принципом необхідної достатності, наступності й перспективності.

Формування економічних знань як базового складника предметної компетентності учнів на уроках географії в освітній системі відбувається на емпіричному рівні, оскільки найкраще розроблений найнижчий рівень розв'язання проблеми - методичний.

Визначаємо актуальність розроблення фундаментальних наукових і дидактичних праць 3 окресленої проблематики задля уникнення переобтяження уроків географії та основ економіки власне економічною інформацією, надання більшої уваги формуванню саме економічних знань.

\section{Література}

1. Алаев Э. Б. Социально-экономическая география: понятийнотерминологический словарь / Энрид Борисович Алаев. - М. : Мысль, 1983. - 350 с. 2. Бондар В. І. Дидактика: [навч. посіб.] / Володимир Іванович Бондар. - К. : Либідь, 2005. - 264 с. 3. Гринюк Т. А. Загальноекономічні та специфічні суспільногеографічні закони та закономірності i розвиток соціальної інфраструктури / Т. А. Гринюк// Географія і сучасність : зб. наукових праць Національного пед. 
університету ім. М. П. Драгоманова. - К., 2002. - Випуск 7. - С. 3-16. 4. Добрович А. Б. Общение: Наука и искусство / А. Б. Добрович. - М. : Знание, 1978. - 143 с. 5. Калмыкова 3. И. Продуктивное мышление как основа обучаемости :[монография] / Зинаида Ильинична Калмыкова. - М.: Педагогика, 1981. - 200 с. 6. Краевский В. В. Теоретические основы профессионального становления молодого педагога / Володар Викторович Краевский. - Самара: СГПУ, 1996. - 167 с. 7. Найденов М. И. Творческий рефлексивно-групповой тренинг / М. И. Найденов, Л. А. Найденова // Интеллектуальные системы и творчество. Новосибирск. - 1991. - С. 86-98. 8. Сиротенко А. Й. Географія України :[пробний підруч. для 9 кл. середн. шк.] / А. Й. Сиротенко, Б. О. Чернов, В. Я. Плахута. - К. : Освіта, 1994. - 223 с. 9. Топузов О. М. Загальна методика навчання географії:[підручник] / О. М. Топузов, В. М. Самойленко, Л. П. Вішнікіна. - . : ДНВП «Картографія», 2012. - 512 с.

УДК 371.315.6:7.01

Ірина Могілей

\section{ХУДОЖНЬО-ЕСТЕТИЧНЕ ВИХОВАННЯ СТАРШОКЛАСНИКІВ ЗАСОБАМИ СУЧАСНОЇ ПОПУЛЯРНОЇ МУЗИКИ}

Могілей I. В. Художньо-естетичне виховання старшокласників засобами сучасної популярної музики.

У статті розглянуто сучасні тенденції викладання художньої культури у старшій школі. На основі аналізу й узагальнення наукової інформації уточнюється сутність дефініцій «естетичне виховання», «художнє виховання», «сучасна популярна музика» в аспекті мистецької освіти. Запропоновано форми й методи художньо-естетичного виховання з використанням сучасної популярної музики.

Ключові слова: естетичне виховання, художнє виховання, мистецька освіта, сучасна популярна музика, урок художньої культури, форми і методи художнього навчання.

Могилей И. В. Художественно-эстетическое воспитание старшеклассников средствами современной популярной музыки.

В статье рассмотрены современные тенденции преподавания художественной культуры в старшей школе. На основе анализа и обобщения научной информации уточняется сущность дефиниций «эстетическое воспитание», «художественное воспитание», «современная популярная музыка» в аспекте художественного образования. Предложены формы и методы художественно-эстетического воспитания с использованием современной популярной музыки.

Ключевые слова: эстетическое воспитание, художественное воспитание, художественное образование, современная популярная музыка, урок художественной культуры,формы и методы художественного обучения.

Mogiley I. V. Artistic and aesthetic education of senior pupils by means of modern popular music.

The article discusses the current trends of teaching art culture in high school. Based onthe analysisandsynthesis of scientific information specified entity definitions «aesthetic education», «art education», «modern popular music» in terms of art formation. Proposed forms and methods of art-aesthetic education with contemporary popular music.

Key words: aesthetic education, art education, art formation, modern popular music, a lesson of art culture, art forms and methods of training.

Кардинальні зміни у всіх галузях життя держави на початку XXI століття 